\title{
Production of thermophilic lactic acid starters in mixed cultures
}

\author{
Catherine Béal*, Georges Corrieu \\ Laboratoire de Génie et Microbiologie des Procédés Alimentaires, Inra-INAPG, \\ 78850 Thiverval-Grignon, France
}

\begin{abstract}
Thermophilic lactic acid starters, Streptococcus thermophilus and Lactobacillus delbrueckii subsp. bulgaricus, were produced by controlled mixed cultures. The total bacterial concentration and the population ratio at the end of fermentation were fixed by the operating conditions ( $\mathrm{pH}$ and temperature) and by the initial percentage of $S$. thermophilus in the inoculum. The suitability of these mixed starters for yoghurt manufacture was determined from their acidification activity. This was not significantly different from that obtained with equivalent mixing of pure cultures. During preservation, the mixed starters were slightly less resistant, both in frozen and freeze-dried forms, than starters obtained from pure cultures. The productivity of the mixed cultures was twice from that obtained with the traditional starter production process, whatever the final population ratio. Finally, the ability to control the mixed starter cultures, the increased productivity and their properties (acidification and preservation) proved their interest for industrial applications. (C) Inra/Elsevier, Paris.
\end{abstract}

\section{thermophilic lactic acid bacteria / mixed culture / starter production}

Résumé - Production de levains lactiques thermophiles en cultures mixtes. La production de ferments lactiques thermophiles, Streptococcus thermophilus et Lactobacillus delbrueckii subsp. bulgaricus, a été réalisée en cultures mixtes maîtrisées. Lors de ces cultures, la concentration bactérienne totale et le rapport des deux populations en fin de culture dépendent des conditions de $\mathrm{pH}$ et de température mises en œuvre et du pourcentage initial de streptocoques dans l'inoculum. L'activité acidifiante des ferments mixtes ainsi obtenus n'est pas significativement différente de celle des mélanges équivalents de ferments produits lors de cultures pures. Toutefois, la résistance à la conservation (sous forme congelée ou lyophilisée) des levains mixtes est un peu moins bonne que celle des levains mélangés. Par comparaison avec la fabrication classique de ferments, réalisée à partir de mélanges de cultures pures, la production en cultures mixtes induit un doublement de la productivité, quel que soit le rapport final de population considéré. Finalement, la maîtrise possible du procédé de production de ferments, les gains de productivité associés, les propriétés de ces levains (activité acidifiante, conservation) assurent l'intérêt de la production industrielle de ferments lactiques en culture mixte. @ Inra/Elsevier, Paris.

bactérie lactique thermophile / culture mixte / production de ferments

\footnotetext{
* Correspondence and reprints
} 


\section{INTRODUCTION}

Thermophilic lactic acid starters are commonly used for the manufacture of fermented milks and especially in yoghurt production [8]. They are generally produced by pure cultures of the two species of lactic acid bacteria Streptococcus thermophilus and Lactobacillus delbrueckii subsp. bulgaricus [7]. The fermentations are $\mathrm{pH}$ and temperature controlled so that high bacterial concentrations are attained. After fermentation, the bacteria are concentrated (by centrifugation or ultrafiltration) and stabilised with a cryoprotective agent. The concentrates are then frozen or freeze-dried and mixed in different proportions according to the specifications of the user [7].

An alternative technique involves the use of controlled $\mathrm{pH}$ mixed cultures, followed by the same preservation treatments [1]. The aim of this work was to produce a maximal amount of bacteria with a well defined proportion of each strain. Operating factors $(\mathrm{pH}$, temperature and inoculation ratio) were used to control the final bacterial concentrations and proportions. The performances of these starters were evaluated for their viability and acidification activity at each step of the production process. They were compared with those of starters obtained traditionally by mixing pure cultures. The productivity of these two methods was compared, from an industrial point of view.

\section{MATERIALS AND METHODS}

\subsection{Strains and culture medium}

The strains used were $S$. thermophilus 404 and $L$. bulgaricus 398 from the collection of Centre National de Recherches Zootechniques (Jouy-en-Josas, France). The medium was composed of mild whey $(60 \mathrm{~g} / \mathrm{L})$ fortified with lactose $(40 \mathrm{~g} / \mathrm{L})$, bactopeptone $(5 \mathrm{~g} / \mathrm{L})$, yeast extract $(5 \mathrm{~g} / \mathrm{L})$ and antifoam $(1 \mathrm{~mL} / \mathrm{L})$. It was sterilised at $110^{\circ} \mathrm{C}$ for $20 \mathrm{~min}$ [3].

\subsection{Fermentations}

Fermentations were carried out in a $15 \mathrm{~L}$ bioreactor (LSL-Biolafitte, France) [3]. Agitation, temperature and $\mathrm{pH}$ were controlled at set-points defined according to the experimental designs. $\mathrm{pH}$ was regulated with $10 \mathrm{~N}$ $\mathrm{NaOH}$.

\subsection{Experimental designs}

Central composite rotatable designs [5] were constructed to characterise the individual, quadratic and interactive effects of $\mathrm{pH}$, temperature and inoculum composition on the growth of $S$, thermophilus and L. bulgaricus in pure and mixed cultures. The results were used to express the final bacterial concentrations and the specific growth rates as second degree polynomial equations $[1,3]$.

\subsection{Concentration and preservation}

The cells were harvested by centrifugation (11 $000 \mathrm{~g}, 15 \mathrm{~min}, 4^{\circ} \mathrm{C}$ ) at the end of the $\log$ phase of the cultures. They were then resuspended in the same volume of milk $(100 \mathrm{~g} / \mathrm{L})$, sterilised at $110^{\circ} \mathrm{C}$ for $15 \mathrm{~min}$ and $10 \mathrm{~g} / \mathrm{L}$ glycerol were added as cryoprotective agent. Half the vials were frozen and stored at $-75^{\circ} \mathrm{C}$. The other half were freeze-dried $\left(12 \mathrm{~h},-15^{\circ} \mathrm{C}, 100 \mathrm{~Pa}\right)$ and stored at $4{ }^{\circ} \mathrm{C}[2]$.

\subsection{Measurement of viability and aci- dification activity}

Viable cells were determined by counting on specific agar, M17 for S. thermophilus and MRS for L. bulgaricus [1]. Acidification activity was measured by using the Cinac system which allowed an on-line recording of $\mathrm{pH}$ and acidification rate $\mathrm{dpH} / \mathrm{dt}(\mathrm{UpH} / \mathrm{min})$ in relation to time [6]. The method was standardised by using the same set of milk and the same inoculation conditions [2]. A single characteristic parameter, $\mathrm{t}_{\mathrm{M}}$ (in min), corresponding to the time necessary to reach the maximum acidification rate, was taken into account. 


\section{RESULTS AND DISCUSSION}

\subsection{Influence of operating conditions on the growth of $S$. thermophilus and $L$. bulgaricus in pure and mixed cultures}

For pure cultures, the combined effects of $\mathrm{pH}$ and temperature on the final bacterial concentrations $\left(\mathrm{X}_{\mathrm{S}}\right.$ and $\mathrm{X}_{\mathrm{L}}$ in cell $\left./ \mathrm{mL}\right)$ were described by polynomials (relations 1 and 2) involving coded values of $\mathrm{pH}$ $(\mathrm{pHc})$ and temperature $(\mathrm{Tc})$. These relationships gave the response surface areas presented in figure 1:

$$
\begin{aligned}
& \mathrm{X}_{\mathrm{S}}=5.1110^{9}-2.1810^{9} \mathrm{pH}_{\mathrm{c}}^{2}-2.1310^{9} \mathrm{~T}_{\mathrm{c}}^{2} \\
& \mathrm{R}_{\mathrm{M}}=0.92 \\
& \mathrm{X}_{\mathrm{L}}=1.8210^{9}-5.7810^{8} \mathrm{pH}_{\mathrm{c}}^{2}-5.3210^{8} \mathrm{~T}_{\mathrm{c}}^{2} \\
& R_{M}=0.76
\end{aligned}
$$

The optimal growth conditions, determined from these equations, were $\mathrm{pH} 6.5$ and $40^{\circ} \mathrm{C}$ for $S$. thermophilus 404 and $\mathrm{pH}$ 5.8 and $44{ }^{\circ} \mathrm{C}$ for $L$. bulgaricus 398 [3].

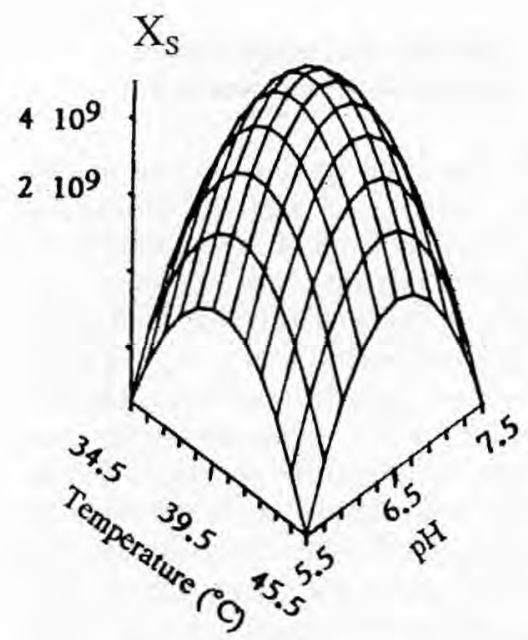

For mixed cultures, the initial percentage of $S$. thermophilus in the inoculum $\left(\mathrm{K}_{0}\right.$ in \%) was a key parameter, in addition to $\mathrm{pH}$ and temperature. This percentage changed during the fermentation, with a first privileged growth of $S$. thermophilus followed by a privileged growth of L. bulgaricus (figure 2). In each case, the bacterial concentrations were higher in mixed cultures than in pure cultures. The polynomials obtained from the experimental designs were used to calculate the final bacterial concentration $\left(X_{F}\right.$ in cell $/ \mathrm{mL}$ ) and the final percentage of S. thermophilus $\left(\mathrm{K}_{\mathrm{F}}\right.$ in \%) in relation to the $\mathrm{pH}$, temperature and initial bacterial ratio [1]:

$$
\begin{gathered}
\mathrm{X}_{\mathrm{F}}=6.8410^{9}+8.710^{8} \mathrm{pHc}-8.910^{8} \mathrm{~K}_{0} \mathrm{c} \\
-6.810^{8} \mathrm{pHc}^{2}-7.510^{8} \mathrm{Tc}^{2} \\
\mathrm{R}_{\mathrm{M}}=0.74
\end{gathered}
$$

$$
\begin{gathered}
\mathrm{K}_{\mathrm{F}}=84.2+15.62 \mathrm{pHc}-6.93 \mathrm{Tc}+3.65 \mathrm{~K}_{0} \mathrm{c} \\
-5.44 \mathrm{Tc}^{2}+3.63 \mathrm{pHc} \cdot \mathrm{Tc}+2.88 \mathrm{Tc} \cdot \mathrm{K}_{0} \mathrm{c} \\
\mathrm{R}_{\mathrm{M}}=0.97
\end{gathered}
$$

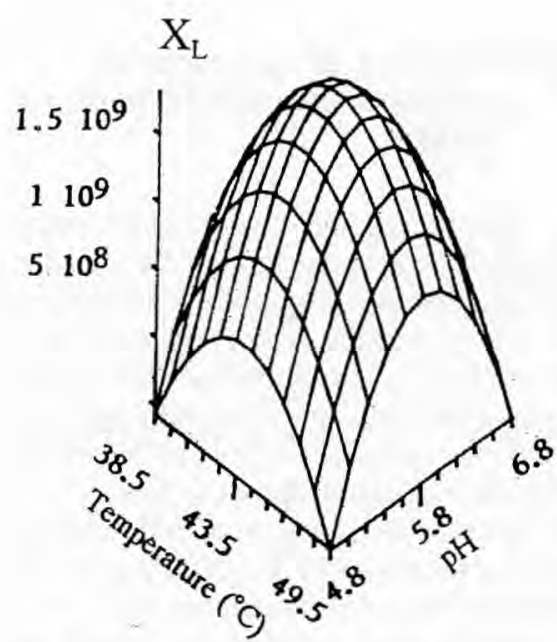

Figure 1. Influence of $\mathrm{pH}$ and temperature on maximal bacterial concentration (in cell $/ \mathrm{mL}$ ) of S. thermophilus $\left(\mathrm{X}_{\mathrm{S}}\right)$ and L. bulgaricus $\left(\mathrm{X}_{\mathrm{L}}\right)$.

Figure 1. Influence du $\mathrm{pH}$ et de la température sur les concentrations bactériennes maximales (en cellules $/ \mathrm{mL}$ ) de $S$. thermophilus $\left(\mathrm{X}_{\mathrm{S}}\right)$ et $L$. bulgaricus $\left(\mathrm{X}_{\mathrm{L}}\right)$. 


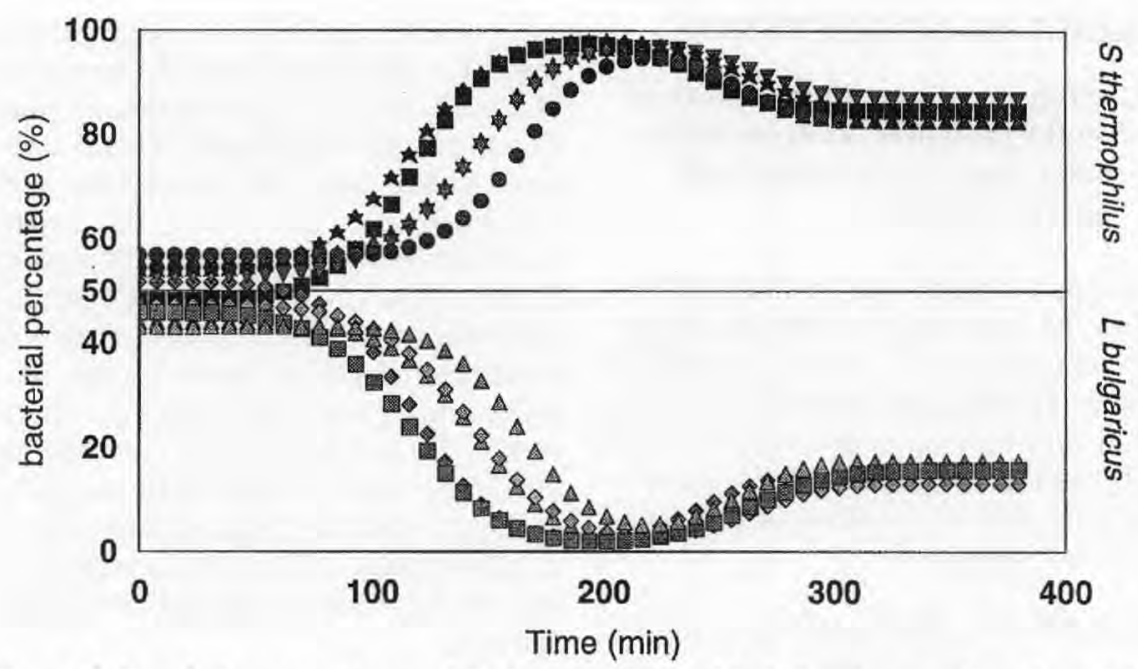

Figure 2. Population percentages of $S$. thermophilus and L. bulgaricus as a function of time (5 experiments, $\mathrm{pH} 6.15,42^{\circ} \mathrm{C}$ ).

Figure 2. Évolution des pourcentages de $S$. thermophilus et $L$. bulgaricus en fonction du temps ( 5 expériences, $\mathrm{pH} 6,15,42^{\circ} \mathrm{C}$ ).

These equations indicated that the experimental conditions had an interactive effect on the final characteristics of the mixed cultures.

\subsection{Prediction of final bacterial concentration and ratio in mixed cultures}

Equations 3 and 4 were used to obtain a simultaneous prediction of the final bacterial concentration and of the ratio of micro-organisms. The operating conditions allowing a maximal bacterial concentration $\left(\mathrm{X}_{\mathrm{F}}\right)$ for a chosen final percentage of $S$. thermophilus $\left(\mathrm{K}_{\mathrm{F}}\right)$ can be determined from the diagram shown in figure 3 [1]. Whatever the $\mathrm{pH}$ and temperature, an initial percentage of $\mathrm{K}_{0}$ of $8 \%$ gave the highest bacterial concentrations. As an example, the conditions allowing the highest population corresponding to a final percentage of S. thermophilus $\mathrm{K}_{\mathrm{F}}=50 \%$ are obtained from figure 3: they corresponded to $\mathrm{pH}=5.63$ and $\mathrm{T}=45.8{ }^{\circ} \mathrm{C}$.
Finally, the production of thermophilic lactic acid starters in mixed cultures could be controlled by the selection of suitable operating conditions.

\subsection{Viability and acidification activity of mixed starters}

The bacterial viability and the acidification activity of starters produced in mixed cultures and of those obtained by equivalent mixing of pure cultures were compared. Due to the standardised inoculation conditions, the time $t_{M}$ (in min), required to attain the maximum acidification rate for the 2 types of starters, was not significantly different (table I). Furthermore, no significant alteration in the acidification activity of the starters was observed during the concentration, freezing and freeze-drying processes, or during 24 of weeks of storage.

The viability of the frozen (storage temperature: $-75^{\circ} \mathrm{C}$ ) and freeze-dried (storage temperature: $4^{\circ} \mathrm{C}$ ) starters, during 
Figure 3. Influence of $\mathrm{pH}$ and temperature (T) on final concentrations $\left(\mathrm{X}_{\mathrm{F}}\right.$ in cell $\left./ \mathrm{mL}\right)$ and ratios $\left(\mathrm{K}_{\mathrm{F}}\right.$ in \%) of $S$. thermophilus and L. bulgaricus in mixed cultures. Inoculation ratio set to $\mathrm{K}_{0}=8 \%$.

Figure 3. Influence du $\mathrm{pH}$ et de la température (T) sur les concentrations finales $\left(\mathrm{X}_{\mathrm{F}}\right.$ en cellules $/ \mathrm{mL}$ ) et les ratios $\left(\mathrm{K}_{\mathrm{F}}\right.$ en \%) de $S$. thermophilus et $L$. bulgaricus en cultures mixtes. Ratio d'inoculation fixé à $\mathrm{K}_{0}=8 \%$.

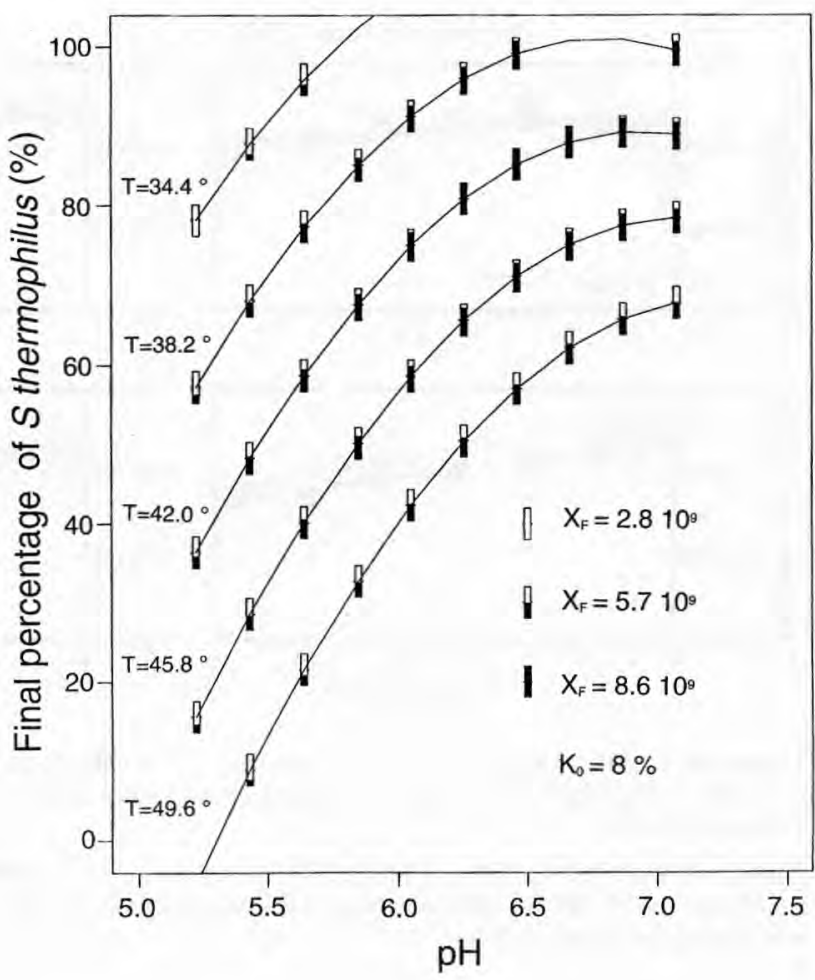

Table I. Time $t_{M}(\mathrm{~min})$ required to attain the maximum acidification rate (Cinac system), of starters obtained by mixing pure cultures and from mixed cultures.

Tableau I. Temps $\mathrm{t}_{\mathrm{M}}(\mathrm{min})$ nécessaire pour atteindre la vitesse d'acidification maximale (système Cinac) par des ferments obtenus par mélanges de cultures pures ou en cultures mixtes.

Treatment Mixing of pure cultures Mixed cultures

\begin{tabular}{lll}
\hline End of fermentation & $254(0.9 \%)$ & $270(1.5 \%)$ \\
Concentration & $262(0.2 \%)$ & $270(0.9 \%))$ \\
Freezing $\left(-75^{\circ} \mathrm{C}\right)$ & $270(1.1 \%)$ & $254(\mathrm{ND})$ \\
24 week storage $\left(-75^{\circ} \mathrm{C}\right)$ & $261(1.9 \%)$ & $220(6.8 \%)$ \\
Freeze-drying & $272(0.8 \%)$ & $264(0.8 \%)$ \\
24 week storage $\left(4^{\circ} \mathrm{C}\right)$ & $263(2.4 \%)$ & $236(6.0 \%)$
\end{tabular}

24 weeks of conservation, decreased continuously (figure 4). This decline was slightly more rapid in the case of the starters obtained from the mixed cultures.

\subsection{Productivity of mixed cultures}

The final total bacterial concentration was 1.4 to 4.9 times higher in the mixed cultures than in the pure cultures. The growth of $S$. thermophilus was stimulated whereas that of L. bulgaricus was not significantly improved. The productivity of the mixed cultures was compared to that of equivalent mixing of pure cultures [2]. Whatever the considered $\mathrm{K}_{\mathrm{F}}$, the productivity was increased by a factor of 1.7 

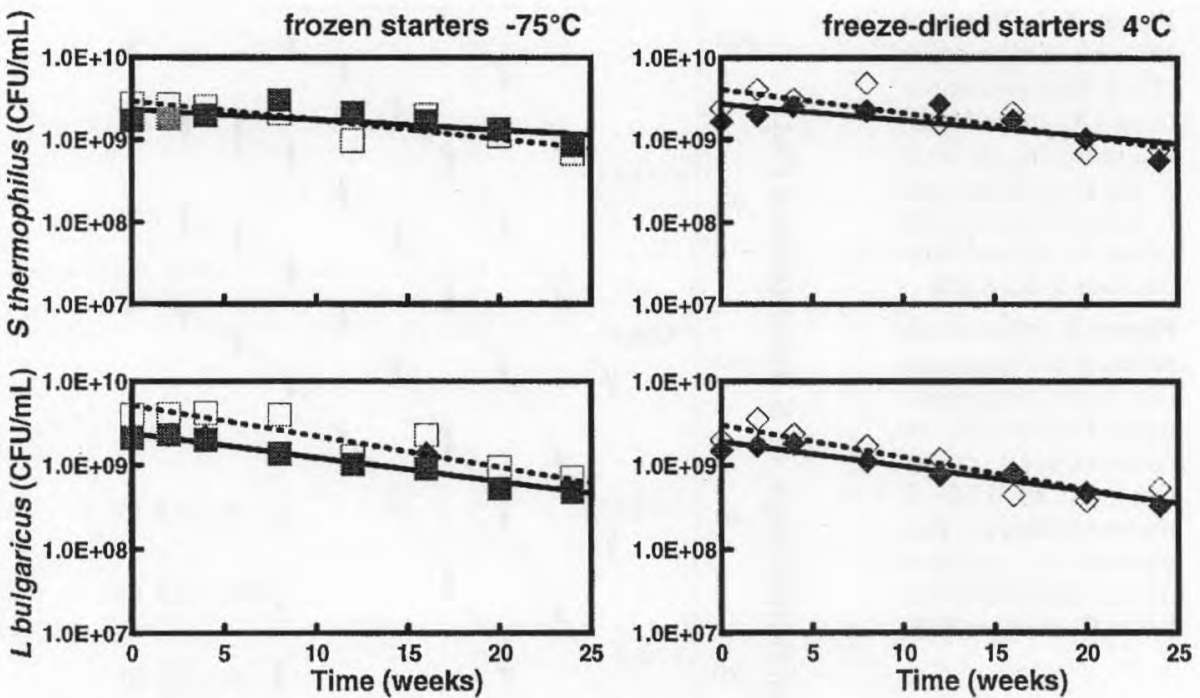

Figure 4. Viability of frozen starters stored at $-75^{\circ} \mathrm{C}(\mathbf{\square}, \square)$ and freeze-dried starters stored at $4{ }^{\circ} \mathrm{C}(\diamond, \diamond)$, issued from a mixed culture (open symbols) and from a mixing of pure cultures (closed symbols).

Figure 4. Viabilité de ferments congelés conservés à $-75^{\circ} \mathrm{C}(\mathbf{\square}, \square)$ et de ferments lyophilisés conservés à $4{ }^{\circ} \mathrm{C}(\bullet, \diamond)$, issus de cultures mixtes (symboles vides) ou formés de mélanges de cultures pures (symboles pleins).

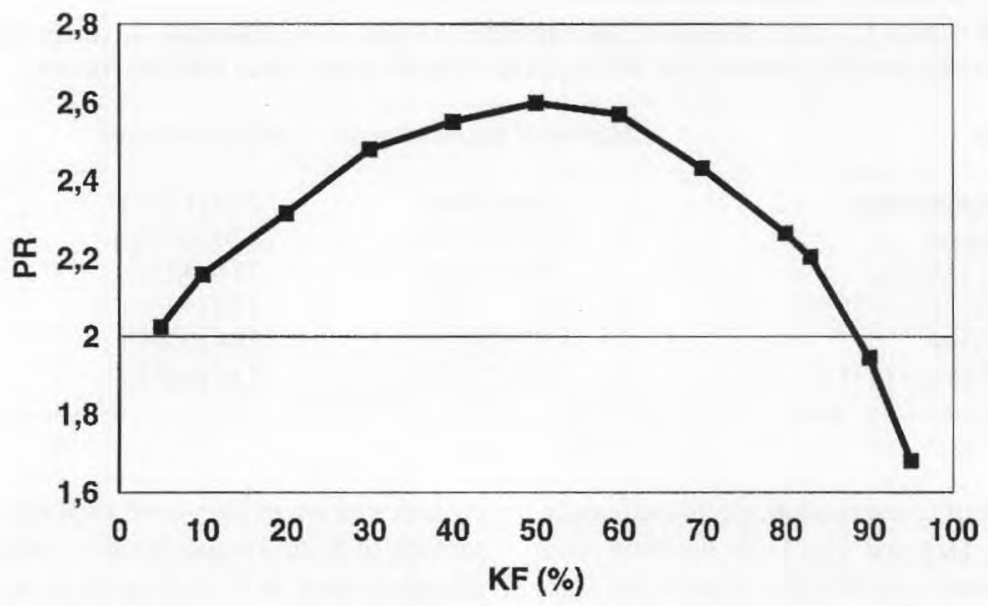

Figure 5. Productivity ratio (PR) obtained for different final percentages of $S$. thermophilus $\left(\mathrm{K}_{\mathrm{F}}\right.$ in \%). $\mathrm{PR}$ is the ratio of mixed culture productivity $\left(\mathrm{P}_{\mathrm{M}}\right)$ and pure culture productivity $\left(\mathrm{P}_{\mathrm{P}}\right)$. Figure 5. Évolution du rapport des productivités (PR) en fonction du pourcentage final de $S$. thermophilus $\left(\mathrm{K}_{\mathrm{F}}\right.$ en \%). PR est le rapport des productivités en culture mixte $\left(\mathrm{P}_{\mathrm{M}}\right)$ et en culture pure $\left(\mathrm{P}_{\mathrm{P}}\right)$. 
to 2.4 in mixed cultures as compared to pure cultures. Figure 5 shows the evolution of the productivity ratio $(\mathrm{PR})$ in mixed $\left(\mathrm{P}_{\mathrm{M}}\right)$ and pure $\left(\mathrm{P}_{\mathrm{P}}\right)$ cultures $\left(\mathrm{PR}=\mathrm{P}_{\mathrm{M}} / \mathrm{P}_{\mathrm{P}}\right)$. The highest value of $P R$ was obtained with a well balanced culture $\left(\mathrm{K}_{\mathrm{F}}=53 \%\right)$. Thus, for equivalent equipment, cultivation time and culture medium consumption, the use of mixed cultures almost double the productivity.

\section{CONCLUSIONS AND PERSPECTIVES}

The industrial implications of such a process may be of considerable interest. In addition to the doubling of productivity during the fermentation step, this cultivation method reduced the number of unit operations involved in the production of lactic acid starters two-fold: medium preparation, bioreactor cleaning and sterilisation, concentration of the bacteria, cryoprotection of the concentrate and freezing and/or freeze-drying. Furthermore, the need to mix the pure starters under sterile conditions is avoided.

However, these results remained specific to the strains used, implying the need to define the fermentation conditions corresponding to each combination of strains. Furthermore, as the behaviour of each bacterial species might differ during the downstream processes [9], the behaviour of the starters during these operations should be checked before using mixed cultures in the production process. Finally, the industrial applications of mixed starter production may be of interest for high volumes of production.

\section{REFERENCES}

[1] Béal C., Corrieu G., Influence of pH, temperature and inoculum composition on mixed cultures of Streptococcus thermophilus 404 and Lactobacillus bulgaricus 398, Biotechnol. Bioeng. 38 (1991) 90-98.

[2] Béal C., Corrieu G., Viability and acidification activity of pure and mixed starters of Streptococcus salivarius subsp. thermophilus 404 and Lactobacillus delbrueckii subsp. bulgaricus 398 at the different steps of their production, Lebensm. Wiss. Technol. 27 (1994) 86-92.

[3] Béal C., Louvet P., Corrieu G., Influence of controlled $\mathrm{pH}$ and temperature on the growth and acidification of pure cultures of Streptococcus thermophilus 404 and Lactobacillus bulgaricus 398, Appl. Microbiol. Biotechnol. 32 (1989) 148-154.

[4] Béal C., Spinnler H.E., Corrieu G., Comparison of growth, acidification and productivity of pure and mixed cultures of Streptococcus salivarius subsp. thermophilus 404 and Lactobacillus delbrueckii subsp. bulgaricus 398, Appl. Microbiol. Biotechnol. 41 (1994) 95-98.

[5] Cochran W.G., Cox G.M., Experimental designs, (2 ${ }^{\text {nd }}$ edn.), Wiley, NY, (1957) 346-349.

[6] Corrieu G., Spinnler H.E., Picque D., Jomier Y, Procédé de mise en évidence et de contrôle de l'activité acidifiante d'agents de fermentation dans des bains de fermentation et dispositif pour sa mise en cuvre, French Patent $\mathrm{n}^{\circ} 8804456$ (1988).

[7] Lejard F., Boyaval P., de Roissart H., Maruejouls R., Production de ferments concentrés pour ensemencement direct, in : Bactéries lactiques (de Roissart H., Luquet S.M., eds.), Lorica, Uriage (1994).

[8] Marschall V.M., Fermented milks and their future trends, I. Microbiological aspects, J. Dairy Res. 54 (1987) 559-574.

[9] Monnet C., Béal C., Corrieu G., Reprise d'activité des ferments lactiques concentrés, Actes du colloque « Microbiologie Industrielle et Environnement ", SFM, Narbonne, 17-20 avril (1996) 415-425. 